\title{
Intratympanic Methylprednisolone Injection in Idiopathic Sudden Sensorineural Hearing Loss after Failure of Systemic Corticosteroid Therapy \\ (Suntikan Metilprednisolon Intratimpanum dalam Idiopati Kurang Pendengaran Sensorineuron Mengejut selepas Kegagalan Terapi Kortikosteroid Sistemik)
}

\author{
HO HON LIAN, RUSZYMAH BINTI IDRUS, LOKMAN BIN SAIM \& AMINUDDIN BIN SAIM*
}

\begin{abstract}
Idiopathic sudden sensorineural hearing loss (ISSNHL) is considered to be an otological emergency. The intratympanic (IT) steroid injection technique is introduced to decrease the side effects of systemic steroids and assumed to deliver a higher concentration of corticosteroids into the affected cochlea. The objective of the current study was to evaluate the hearing outcomes of high dose IT methylprednisolone among ISSNHL patients after failure of systemic corticosteroid therapy (SCT). Hearing outcomes of SCT were evaluated over a 15 months period. Upon failure of SCT, the treatment was continued with higher dose IT steroid (methylprednisolone $62.5 \mathrm{mg} / \mathrm{mL}$ ). Pre-treatment and post-treatment audiometric evaluations were analysed using pure tone audiogram (PTA). There were 36 patients diagnosed with ISSNHL included in the study. After two weeks of SCT, eighteen (56.3\%) patients had hearing improvement of more than $10 \mathrm{~dB}$. Another fourteen (43.7\%) patients had no hearing improvement (less than $10 \mathrm{~dB}$ ). Following that, twelve patients were recruited for weekly IT methylprednisolone for three weeks. During the one month follow up after completion of IT therapy, six patients (50\%) showed more than $10 \mathrm{~dB}$ improvement in the PTA with a mean of $19.37 \mathrm{~dB}(\mathrm{p}<0.05)$. Out of the six, two patients had more than $20 \mathrm{~dB}$ hearing improvement. Almost all patients in this study had an improvement in their symptoms of tinnitus and vertigo. High dose IT methylprednisolone after failure of SCT resulted in significant improvement in the patients' hearing outcome during one month follow up. The IT therapy not only improved the patients' hearing but in addition reduced the symptoms of tinnitus and vertigo.
\end{abstract}

Keywords: Intratympanic; methylprednisolone; sudden hearing loss

\section{ABSTRAK}

Kehilangan pendengaran sensorineuron mengejut idiopati (ISSNHL) dianggap sebagai kecemasan otologi. Teknik suntikan steroid intratimpanum (IT) diperkenalkan untuk mengurangkan kesan sampingan steroid sistemik dan diandaikan memberi tumpuan yang lebih tinggi daripada kortikosteroid ke koklea yang terjejas. Objektif kajian adalah untuk menilai hasil pendengaran dos yang tinggi metilprednisolon IT dalam kalangan pesakit ISSNHL selepas kegagalan terapi sistemik kortikosteroid (SCT). Laporan hasil SCT telah dinilai dalam tempoh 15 bulan. Atas kegagalan SCT, rawatan diteruskan dengan dos IT steroid yang tinggi (metilprednisolon $62.5 \mathrm{mg} / \mathrm{mL}$ ). Penilaian pra dan pasca rawatan audiometrik dianalisis menggunakan audiogram bernada tulen (PTA). Terdapat 36 pesakit yang didiagnosis dengan ISSNHL terlibat dalam kajian ini. Selepas dua ming gu SCT, lapan belas (56.3\%) pesakit mempunyai peningkatan pendengaran melebihi $10 \mathrm{~dB}$. Empat belas (43.7\%) pesakit lain tidak mempunyai sebarang kemajuan pendengaran (kurang daripada $10 \mathrm{~dB}$ ). Berikutan itu, dua belas pesakit telah diambil bekerja untuk mingguan IT metilprednisolon selama tiga minggu. Pada bulan pertama susulan selepas selesai terapi IT, enam pesakit (50\%) menunjukkan lebih daripada 10 dB peningkatan dalam PTA dengan min $19.37 \mathrm{~dB}$ (p<0.05). Daripada enam, dua pesakit mempunyai lebih daripada 20 dB penambahbaikan pendengaran. Hampir semua pesakit dalam kajian ini menunjukkan penambahbaikan dalam gejala tinitus dan vertigo mereka. Dos tinggi IT metilprednisolon selepas kegagalan SCT telah mengakibatkan peningkatan yang ketara dalam keputusan pendengaran pesakit sepanjang sebulan susulan. Terapi IT bukan sahaja memperbaiki pendengaran pesakit tetapi mengurangkan gejala tinitus dan vertigo.

Kata kunci: Intratimpanum; metilprednisolon; kehilangan pendengaran mengejut

\section{INTRODUCTION}

In Otolaryngology and Audiology practices, Idiopathic Sudden Sensorineural Hearing Loss (ISSNHL) is considered to be an otological emergency. ISSNHL is defined as a decline in hearing over a period of $72 \mathrm{~h}$ or less and affecting 3 or more frequencies by $30 \mathrm{~dB}$ or greater (American
Hearing Research Foundation). Approximately 5-20 persons in 100,000 populations of patients who suffer from ISSNHL consult an otolaryngologist yearly (Abdullah et al. 2006; Chau et al. 2010; Kuhn et al. 2011).

Considering that there is no standard protocol or universally accepted way to treat patients with ISSNHL, 
various therapies and agents such as steroids (systemic and local intratympanic), plasma expander, antiviral agents, anticoagulants, vasodilators, diuretics, vitamins, hyperbaric oxygen therapy and topical insulin-like growth factor therapy have been proposed as therapeutic agents to treat sudden sensorineural hearing loss (Ferri et al. 2012; Rausch et al. 2011).

Systemic glucocorticoid is the most commonly used treatment for ISSNHL, since most cases of ISSNHL are due to an infectious, inflammatory or autoimmune process. In such cases, ISSNHL is usually treated with prednisolone or dexamethasone where the recommended dosage varies from 1 to 10 milligrams per kilogram of body weight. Improvements in hearing after systemic corticosteroid therapies, occurs in $50 \%$ of patients. However, approximately $20 \%$ of patients showed no improvement at all (Battaglia et al. 2008; Kong et al.2014; Wang et al. 2016).

Use of intratympanic (IT) steroid was evident since year 1991. Over the past decades, IT corticosteroid treatment is beginning to be more accepted in the treatment of ISSNHL due to the low probability of systemic adverse events and also due to the potential delivery of high concentrations of corticosteroid into the inner ear (Arastou et al. 2013). However, studies done on IT corticosteroid employed a wide variation in terms of the dosage. To the best of our knowledge, no study has been done with IT steroid dosage of more than $60 \mathrm{mg} / \mathrm{mL}$ concentration. Thus, in the current study, the highest concentration of steroid available is employed to evaluate the possible hearing improvement outcomes as well as its possible side effects.

In ISSNHL, tinnitus and vertigo is the most common associated symptoms with $72-84 \%$ of patients suffering from tinnitus (Bennet et al. 2005; Mazita et al. 2008; Wan et al. 2013) and $40 \%$ patients complain of dizziness, vertigo, disequilibrium, imbalance or Meniere's like vertigo. Two studies suggested that IT steroid is also a good modality option in treating ISSNHL patients with Meniere like vertigo and tinnitus (Deenadayal et al. 2016; Noell et al. 2003; Ruszymah et al. 2005).

\section{PATIENTS AND METHODS}

This clinical descriptive study was approved by the KPJ University College (KPJUC) Ethical Committee (KPJUC/M.ORL/EC/2015/004). The study was carried out in the Otorhinolaryngology Clinic, KPJ Ampang Puteri Specialist Hospital from 1st of March 2015 to 30th June 2016. Universal sampling technique was used in this study and consents were taken from the patients prior to the onset of study. The patients' age ranged between 18 and 60 years old, with ISSNHL of more than $30 \mathrm{~dB}$ at three consecutive frequencies within 3 days with normal hearing in the contralateral ear. IT steroid injections were given in patients with recovery of less than $10 \mathrm{~dB}$ after a two week's treatment of systemic steroid.

After a complete history taking, clinical examinations, pure tone audiogram (PTA) and several laboratory investigations (full blood count, coagulation profile, serum glucose, antinuclear antigen and serology for syphilis) were done. Magnetic resonance imaging (MRI) examinations of brain and cerebellopontine angle was performed on all patients to rule out intracranial retrocochlear pathology.

\section{SYSTEMIC CORTICOSTEROIDS THERAPY}

All the ISSNHL patients were given a two-week course of systemic steroid therapy of intravenous dexamethasone for 1 week and continued with oral prednisolone of 10 $\mathrm{mg} /$ body weight in tapering dose for another 8 days. Esomeprazole, $40 \mathrm{mg}$ BD for two weeks, was given to the patients with risks of developing gastritis.

PTA is repeated after completion of two-week systemic steroid and patients with less than $10 \mathrm{~dB}$ improvement in PTA, averaged at four tested frequencies $(500,1000,2000$ and $4000 \mathrm{~Hz}$ ) were included in the IT methylprednisolone study.

\section{INTRATYMPANIC METHYLPREDNISOLONE INJECTION}

Examinations of ears done under microscope and the external ear canal were cleansed using normal saline and suction under microscope.

The patient was placed in supine position, with the head tilted 45 degrees to the healthy ear side. Local anaesthesia was administrated using 5\% EMLA cream (1 g contains $25 \mathrm{mg}$ of Lidocaine and $25 \mathrm{mg}$ of prilocaine) pasted on the tympanic membrane and outer ear canal. A $3 \mathrm{cc}$ syringe filled with methylprednisolone $(62.5 \mathrm{mg} / \mathrm{mL})$ attaches to a $25 \mathrm{G}$ spinal needle and around $0.3-0.5 \mathrm{~mL}$ of methylprednisolone was injected into middle ear cavity at the anterior inferior quadrant of the tympanic membrane. The patient then lied laterally on the healthy site for $30 \mathrm{~min}$ after the procedure and was instructed to avoid yawning, coughing and speaking for $30 \mathrm{~min}$. The procedure was repeated weekly for 3 weeks.

An improvement of $20 \mathrm{~dB}$ or the hearing thresholds below $20 \mathrm{~dB}$ (normal hearing) in the PTA average at 0.5 , $1.0,2$ and $4 \mathrm{kHz}$ was considered as an improvement in hearing.

\section{STATISTICAL ANALYSIS}

IBM SPSS statistics version 23 and Microsoft Excel was used for data analysis. The comparison of mean PTA average before and after SCT and IT methylprednisolone therapy were assessed with Wilcoxon Signed Rank Test due to a smaller sample size. A $p$ value $\leq 0.05$ was considered significant. All the result are being expressed as mean +/- SEM.

\section{RESULTS}

Among the total of 4436 patients that visited the otorhinolaryngology outpatient clinic during our study period, 350 were with hearing problems and $36(0.81 \%)$ were diagnosed with ISSNHL. There were $23(63.9 \%)$ 
female and $13(36.1 \%)$ male patients. The most common associated symptom in the patients was tinnitus which was seen in 28 out of 36 patients $(77.8 \%)$, followed by vertigo in eight out of $36(22.2 \%)$ patients. About $11.1 \%$ of patients had history of associated upper respiratory tract infection symptoms. There was only one patient $(2.7 \%)$ who had associated history of otalgia.

A total of 32 patients completed the two weeks course of SCT. Eighteen patients $(56.3 \%)$ had improvement of more than $10 \mathrm{~dB}$ in PTA average measurement posttreatment. Fourteen $(43.7 \%$ ) patients had no improvement or an average improvement in PTA of less than $10 \mathrm{~dB}$. Two patients refused IT injections.

Twelve patients were recruited for IT methylprednisolone therapy. All the 12 patients received weekly IT injections for three weeks.

One month after completion of IT therapy, six of twelve patients showed more than $10 \mathrm{~dB}$ improvement in the PTA test with a median of $19.37 \mathrm{~dB}(p<0.05)$. Two patients had more than $20 \mathrm{~dB}$ hearing improvement.

The hearing outcome improved for all the mild, moderate and severe-profound hearing loss groups. Mild hearing loss group had a $10.9 \mathrm{~dB}$ improvement, moderate hearing loss improves by $19.07 \mathrm{~dB}$ and severe-profound improves by $14.69 \mathrm{~dB}$ (Figure 1).

All the hearing significantly improves after each IT injections $(p<0.05)$. The most significant improvement is after the third IT therapy $(p<0.005)$ (Table 1$)$.

We included the hearing thresholds before and after IT injections in the four frequencies tested $(500,1000,2000$ and $4000 \mathrm{~Hz})$. The lowest frequency $(500 \mathrm{~Hz}) \mathrm{had}$ the highest gain of $14 \mathrm{~dB}$ after IT therapy $(p<0.05)$ followed by $4000 \mathrm{~Hz}$ at $11.67 \mathrm{~dB}$ gained $(p<0.05), 2000 \mathrm{~Hz}$ at 7.22 $\mathrm{dB}(p<0.05)$ and $1000 \mathrm{~Hz}$ at $6.67 \mathrm{~dB}(p<0.05)$ (Table 2).

In this study, seven out of 12 patients had tinnitus and vertigo during the presentation. After IT methylprednisolone injections, only one patient suffered continuous tinnitus and vertigo while other improves significantly (Figure 2).

\section{DISCUSSION}

There were 32 patients who completed the two weeks treatment of systemic corticosteroids therapy. Out of these, 18 patients experienced hearing improvement of more than $10 \mathrm{~dB}$ with two regaining normal hearing and 14 patients showed no improvement at all. This was comparable with the previous studies done in which only $45-75 \%$ of patients regained normal hearing after SCT (Chandrasekhar 2003; Cinamon et al. 2001; Tucci et al. 2002). Those who failed to have any significant improvement of more than $10 \mathrm{~dB}$ with SCT were included in our study and given weekly IT injection of methylprednisolone for 3 weeks duration.

In the current study, higher dosage of methylprednisolone $(62.5 \mathrm{mg} / \mathrm{mL})$ was selected because higher concentration of steroid was proven to be more effective as it remained longer in the perilymph (Parnes et al. 1999). Ho et al. (2004) later showed that weekly intervals of IT corticosteroids for three injections was proven to be better compared to the first two injections. In

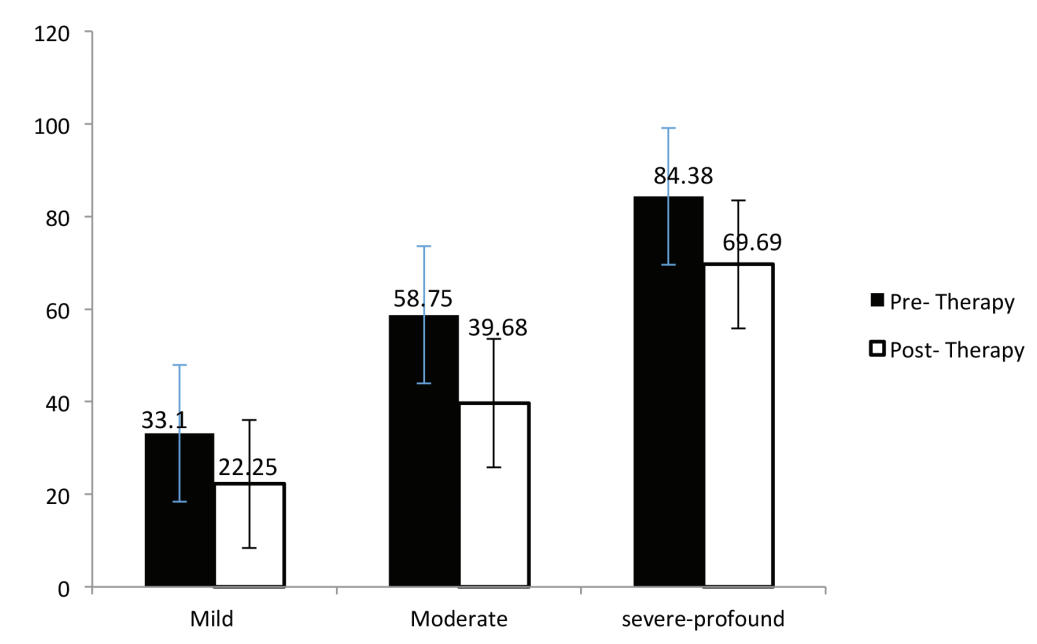

FIGURE 1. Mean PTA average pre and post-therapy according to the level of hearing loss

TABLE 1. Hearing outcomes after SCT and each IT

\begin{tabular}{lcc}
\hline Duration & Mean of PTA (dB) +/- SD & P-value \\
\hline Post SCT & $56.37+/-25.28$ & 0.005 \\
Post IT procedure week 1 & $55.87+/-27.93$ & 0.007 \\
Post IT procedure week 2 & $50.95+/-26.98$ & 0.005 \\
Post IT procedure week 3 & $48.50+/-25.86$ & 0.002 \\
1 month follow up & $50.00+/-25.66$ & 0.002 \\
\hline
\end{tabular}


TABLE 2. Hearing Thresholds before and after IT procedure in each frequency

\begin{tabular}{ccccc}
\hline $\begin{array}{c}\text { Frequency } \\
(\mathrm{Hz})\end{array}$ & $\begin{array}{c}\text { Before IT procedure } \\
(\text { Mean PTA, dB) }+/- \text { SD }\end{array}$ & $\begin{array}{c}\text { Post procedure } \\
(\text { Mean PTA, dB) }+/- \text { SD }\end{array}$ & $\begin{array}{c}\text { PTA differences }(\mathrm{dB}) \\
+/- \text { SD }\end{array}$ & $\begin{array}{c}\text { P-value } \\
\text { (Wilcoxon Test) }\end{array}$ \\
\hline 500 & $66.00+/-26.20$ & $52.00+/-21.07$ & $14.00+/-14.65$ & 0.05 \\
1000 & $63.89+/-27.67$ & $57.22+/-31.28$ & $6.67+/-15.48$ & 0.01 \\
2000 & $62.22+/-30.78$ & $55.00+/-29.84$ & $7.22+/-15.49$ & 0.02 \\
4000 & $60.00+/-29.63$ & $48.33+/-29.49$ & $11.67+/-14.49$ & 0.03 \\
\hline
\end{tabular}

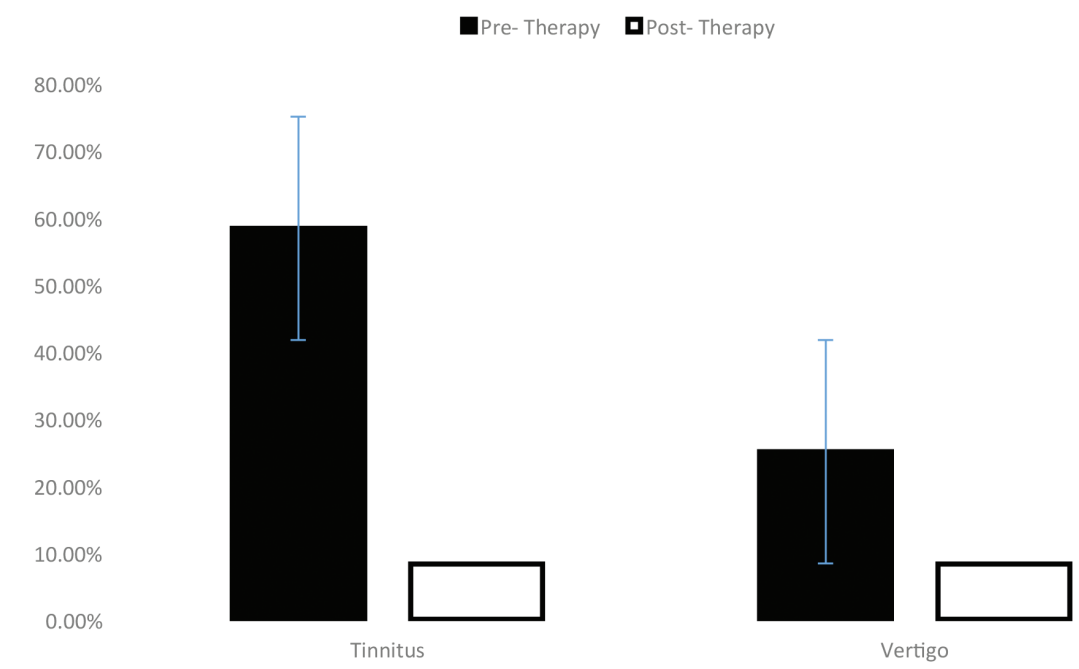

FIGURE 2. Treatment outcomes in tinnitus and vertigo after IT procedure

2010, Raymundo et al. recruited 14 patients treated with three intratympanic methylprednisolone injections after failed SCT and showed that ten of $14(71.4 \%)$ patients had hearing recovery of more than $20 \mathrm{~dB}$. However, none of the mentioned studies used a concentration of more than $40 \mathrm{mg} / \mathrm{mL}$. The current study is the first report of the use of the highest concentration of IT steroid, $62.5 \mathrm{mg} / \mathrm{mL}$, with no untoward side effect to the patients after the IT procedure.

During one month follow up after the completion of IT therapy, six of 12 patients showed more than 10 $\mathrm{dB}$ improvement in the PTA with a median of $19.37 \mathrm{~dB}$ $(p<0.05)$. Four patients had more than $20 \mathrm{~dB}$ hearing improvement. The improvements in other studies showed inconsistent results, with improvements range from 13 to $75 \%$ after IT injections, either as a sole procedure or in combination of systemic steroids (Arslan et al. 2011; Moon et al. 2011; Spear \& Schwartz 2011). This variation might be due to the difference in the concentration of steroid being used, or other factors such as the duration of first treatment and age. In our study, $50 \%$ of the patients did have improvement after 3 weeks IT procedure using high dose of methylprednisolone. This percentage, though even is on the higher range, does not prove to be of any advantage compared to the lower dosage of steroid done in previous studies. In addition, there was no significant side effect noted in all of our patients.

It is well known, factors such as delayed onset of treatment and presentation of severe to profound SSNHL, are signs of poor prognosis. In the current study, there were four patients presented with severe-profound sensorineural hearing loss on arrival with the mean PTA of $85.00 \mathrm{~dB}$. After completion of the IT therapy, the mean PTA improved to $69.7 \mathrm{~dB}$. None of these patients later regained normal hearing. However, none of them showed deteriorating mean PTA either. In fact, one of the patients are able to have improvement from profound to severe hearing loss with a PTA average gained of 16.25 $\mathrm{dB}$. This is also comparable to other studies that showed improvement and more importantly the prevention of deterioration of hearing loss in severe SSNHL (Battaglia et al. 2008; Gundongan et al. 2013; Jong et al. 2010). This shows that IT procedure is important not only in gaining some recovery but also important in preventing further deterioration in severe to profound ISSNHL patients.

Tinnitus and vertigo are other symptoms associated with ISSNHL, which could be a frightening experience to the patients. Previous studies have shown that the symptom of tinnitus decreased from $70 \%$ to $30 \%$ after 7 to 10 days SCT. In IT steroid procedure the improvement is much higher, ranging from $75 \%$ to $100 \%$ (Choi et al. 2013; Hyun 2016; Mühlmeier et al. 2016). In the current study, in terms of tinnitus, there was a significant improvement in 7 out of 8 patients. The same goes with the symptom of vertigo, which have a higher range of improvement in SSNHL after IT procedure of nearly $100 \%$ (Alexander et al. 2015; Deenadayal et al. 2016b; She et al. 2009). In our study, the vertigo disappears in three out of 4 patients. 


\section{CONCLUSION}

The incidence of ISSNHL is rare and in our outpatient department accounts for $0.81 \%$. Most of the patients presented to the ENT clinic quite early, with a mean of 4.8 days and all of them received treatment in less than two weeks.

There were $56.3 \%$ of patients with ISSNHL and their hearing improves after 2 weeks course of SCT. IT methylprednisolone procedure, significantly improves the hearing of $50 \%$ of the patients who previously not responding to SCT. However, these percentages are not different from other study that use lower concentration of steroid. The higher concentration does not have any short or long-term side effect. The procedure is also proven in improving the associated symptoms of tinnitus and vertigo.

\section{ACKNOWLEDGEMENTS}

We thank Zalita Abd Aziz for her assistance in data collection and Abid Nordin for valuable discussions.

\section{REFERENCES}

Abdullah, A., Hazim, M.Y., Almyzan, A., Jamilah, A.G., Roslin, S., Ann, M.T., Borhan, L., Sani, A., Lokman, S. \& Boo, N.Y. 2006. Newborn haring screening: Experience in a Malaysia hospital. Singapore Medical Journal 47(1): 60-64.

Alexander, T.H., Harris, J.P., Nguyen, Q.T. \& Vorasubin, N. 2015. Dose effect of intratympanic dexamethasone for idiopathic sudden sensorineural hearing loss: $24 \mathrm{mg} / \mathrm{mlL}$ is superior to $10 \mathrm{mg} / \mathrm{mL}$. Otology \& Neurotology 36: 1321-1327.

Arastou, S., Tajedini, A. \& Borghei, P. 2013. Combined intratympanic and systemic steroid therapy for poorprognosis sudden sensorineural hearing loss. Iranian Journal of Otorhinolaryngology 1(25): 23-28.

Arslan, N., Oğuz, H., Demirci, M., Şafak, M.A., İslam, A., Kaytez, S.K. \& Samim, E. 2011. Combined intratympanic and systemic use of steroids for idiopathic sudden sensorineural hearing loss. Otology \& Neurotology 32: 393-397.

Battaglia, A., Burchette, R. \& Cueva, R. 2008. Combination therapy (intratympanic dexamethasone + high-dose prednisolone taper) for the treatment of idiopathic sudden sensorineural hearing loss. Otology \& Neurotology 28: 453-460.

Bennet, M., Kertesz, T. \& Yeung, P. 2005. Hyperbaric oxygen therapy for idiopathic sudden sensorineural hearing loss and tinnitus: A systematic review of randomized controlled trials. Journal of Laryngology \& Otology 119: 791-798.

Chandrasekhar, S.S. 2003. Updates on methods to treat sudden hearing loss. Operative Techniques in Otolaryngology-Head and Neck Surgery 14: 288-292.

Chau, J.K., Lin, J.R., Atashband, S., Irvine, R.A. \& Westerberg, B.D. 2010. Systematic review of the evidence for the etiology of adult sudden sensorineural hearing loss. Laryngoscope 120: 1011-1021.

Choi, S.J., Lee, J.B., Lim, H.J., In, S.M., Kim, J.Y., Bae, K.H. \& Choung, Y.H. 2013. Intratympanic dexamethasone injection for refractory tinnitus: Prospective placebo-controlled study. Laryngoscope 123: 2817-2822.

Cinamon,U.,Bendet, E.\& Kronenberg,J.2001. Steroids, carbogen or placebo for sudden hearing loss: A prospective double- blind study. European Archives of Otorhinolaryngology 258: 477-480.

Deenadayal, D.S., Vidyasagar, D., Bommakanti, V., Goel, K. \& Naeem, N. 2016a. Role of intratympanic steroids in the management of Meniere's disease-A review of 151 cases. International Journal of Otolaryngology and Head \& Neck Surgery 5: 108-113.

Deenadayal, D.S., Vidyasagar, D., Vyshanavi, B., Madisetty, N.K., Nakirikanti, R.K. \& Ramesh, C. 2016b. Role of intratympanic steroids in the management of idiopathic sudden sensori neural hearing loss - our experience of 67 cases. International Journal of Otolaryngology and Head \& Neck Surgery 5: 174-180.

Ferri, E., Frisina, A., Fasson, A.C., Armato, E., Spinato, G. \& Amadori, M. 2012. Intratympanic steroid treatment for idiopathic sudden sensorineural hearing loss after failure of intravenous therapy. ISRN Otolaryngology 2012: 647271.

Gundogan, O., Pinar, E., Imre, A., Ozturkcan, S., Cokmez, O. \& Yigiter, A.C. 2013. Therapeutic efficacy of the combination of intratympanic methylprednisolone and oral steroid for idiopathic sudden deafness. Otolaryngology Head \& Neck Surgery 149: 753-758.

Ho, H.G., Lin, H.C., Shu, M.T., Yang, C.C. \& Tsai, H.T. 2004. Effectiveness of intratympanic dexamethasone injection in sudden-deafness patients as salvage treatment. Laryngoscope 114: 1184-1189.

Hyun, J.S. 2016. Intratympanic steroid injection in tinnitus management. Hanyang Medical Review 36: 125-130.

Jong, D.L., Moo, K.P., Chi, K.L., Kye, H.P. \& Byung, D.L. 2010. Intratympanic steroids in severe to profound sudden sensorineural hearing loss as salvage treatment. Clinical and Experimental Otorhinolaryngology 3: 122-125.

Kong, M.H., Goh, B.S., Hamidah, A. \& Zarina, A. 2014. The prevelance of sensorineural hearing loss in B-thalassemia patient treated with Desferrioxime. Medical Journal Malaysia 69(1): 9-12.

Kuhn, M., Heman-Ackah, S.E., Shaikh, J.A. \& Roehm, P.C. 2011. Sudden sensorineural hearing loss: A review of diagnosis, treatment, and prognosis. Trends in Amplification 15: 91-105.

Mazita, A., Abdullah, A., Awang, M.A., Liyab, B. \& Lokman, S. 2008. Relation of distortion product optoacoustic emission with tinnitus. Laryngocope 118(4): 712-717.

Moon, I.S., Lee, J.D., Kim, J., Hong, S.J. \& Lee, W.S. 2011. Intratympanic dexamethasone is an effective method as a salvage treatment in refractory sudden hearing loss. Otology \& Neurotology 32: 1432-1436.

Mühlmeier, G., Baguley, D., Cox, T., Suckfüll, M. \& Meyer, T. 2016. Characteristics and spontaneous recovery of tinnitus related to idiopathic sudden sensorineural hearing loss. Otology \& Neurotology 37: 634-641.

Noell, C. \& Meyerhoff, W. 2003. Tinnitus. Diagnosis and treatment of this elusive symptom. Geriatrics 58: 28-34.

Parnes, L.S., Sun, A.H. \& Freeman, D.J. 1999. Corticosteroid pharmacokinetics in the inner ear fluids: An animal study followed by clinical application. Laryngoscope 109: 1-17.

Rausch, S.D., Halpin, C.F., Antonelli, P.J., Babu, S., Carey, J.P., Gantz, B.J., Goebel, J.A., Hammerschlag, P.E., Harris, J.P., Isaacson, B., Lee, D., Linstrom, C.J., Parnes, L.S., Shi, H., Slattery, W.H., Telian, S.A., Vrabec, J.T. \& Reda, D.J. 2011. Oral vs intratympanic corticosteroid therapy for idiopathic sudden sensorineural hearing loss: A randomized trial. Journal of the American Medical Association 305: 2071-2079. 
Raymundo, I.T., Bahmad, F.J., Barros Filho, J., Piaheiro Pinheiro, T.G. \& Oliveira, C.A. 2010. Intratympanic methylprednisolone as rescue therapy in sudden sensorineural hearing loss. Brazilian Journal of Otorhinolaryngology 76(4): 499-509.

Ruszymah, B., Farah, W., Zakinah, Y., Zahari, Z., Norazlinda, Lokman, S. \& Aminuddin, B.S. 2005. Congenital deafness: High prevalence of a V371 mutation in the GJB2 gene among deaf school children in Alor Setar. Medical Journal Malaysia 60(3): 269-271.

She, W., Dai, Y., Du, X., Chen, F., Ding, X. \& Cui, X. 2009. Treatment of subjective tinnitus: A comparative clinical study of intratympanic steroid injection vs. oral carbamazepine. Medical Science Monitor 15: 135-139.

Spear, S.A. \& Schwartz, S.R. 2011. Intratympanic steroids for sudden sensorineural hearing loss: A systematic review. Otolaryngology Head and Neck Surgery 145: 534-543.

Trowbridge, B.C. 1949. Tympanosympathetic anesthesia for tinnitus aurium and secondary otalgia. Archives of Otolaryngology 50: 200-215.

Tucci, D.L., Farmer, J.C., Kitch, R.D. \& Witsell, D.L. 2002. Treatment of sudden sensorineural hearing loss with systemic steroids and valacyclovir. Otology \& Neurotology 23: 301308.

Wan, S.I., Fei, Z., Deepak, R. \& Mohammed, A. 2013. Measurement of subtle auditory deficit in tinnitus patients with normal audiometric thresholds using evoked optoacoustic emissions and threshold equalizing noise test. International Tinnitus Journal 18(1): 35-44.

Wang, M., Han, Y., Fan, Z., Zhang, D. \& Wang, H. 2016. Therapeutic effect on idiopathic sudden sensorineural hearing loss with duration of onset more than 3 months. Indian Journal of Otolaryngology and Head \& Neck Surgery 65: 61-65.
Ho Hon Lian, Lokman Bin Saim \& Aminuddin Bin Saim* KPJ Healthcare University College

Lot PT 17010, Persiaran Seriemas

Kota Seriemas

71800 Nilai, Negeri Sembilan Darul Khusus

Malaysia

Ruszymah Binti Idrus

Department of Physiology

UKM Medical Faculty

Jalan Yaacob Latif, Bandar Tun Razak, Cheras

56000 Kuala Lumpur, Federal Territory

Malaysia

Ho Hon Lian \& Aminuddin Bin Saim*

Department of Otorhinolaryngology Head and Neck Surgery KPJ Ampang Puteri Specialist Hospital

Jalan Mamanda 9, Taman Ahmad Razali

Ampang Jaya

68000 Ampang, Selangor Darul Ehsan

Malaysia

*Corresponding author; email: aminuddin_saim@yahoo.com

Received: 28 March 2018

Accepted: 30 July 2018 